\title{
Visualizing Development with Identity Relational Aesthetics of Indigenous Collaborative Community Art Projects
}

\author{
Pauline Oosterhoff, Arno Peeters and Iris Honderdos
}

\section{Introduction}

Balancing indigenous and minority people's economic development with the preservation of their cultural heritage is a critical issue in contemporary discussions among both ethnographic museums and development experts. The right to development for indigenous peoples, along with the preservation of their identity, has been widely recognized by various international treaties and laws. ${ }^{1}$ Many indigenous peoples have asserted at many international forums where this right to identity was discussed that the dominant development paradigm and globalization are causing the destruction of their indigenous economic, social and cultural systems. These claims are also validated by policy-oriented research on indigenous peoples and development. ${ }^{2}$ Representatives of minorities and indigenous peoples demand the right to choose their own development path - development with culture and identity - in a number of international organizations, such as the UN Permanent Forum on Indigenous Issues. However, there is a diversity of identities within indigenous and minority communities, such as those based on gender and age. ${ }^{3}$ Recognizing such

1 The terms "Development with Identity" and "Development with Culture and Identity" are adopted by UN agencies and the World Bank and can be traced back to various legal instruments such as International Human Rights Law (e.g. UN Human Rights Declaration, International Covenants on Civil and Political Rights and Economic, Social and Cultural Rights, International Convention on the Elimination of all Forms of Racial Discrimination, Convention on the Rights of the Child, CEDAW. See also for example: International Expert Group Meeting on Indigenous Peoples: Development with Culture and Identity: Articles 3 and 32 of the United Nations Declaration on the Rights of Indigenous Peoples, 12-14 January 2010: <www.un.org/esa/socdev/unpfii/documents/EGM_DCI_Concept_Paper.doc>, visited on 12 August 2013. And Tauli-Corpuz, Victoria, The Concept of Indigenous Peoples' self-determined development or development with identity and culture: challenges and trajectories (Tebtebba Foundation, CLT/CPD/CPO/2008/IPS/o2 (UNESCO Publishers, 2008).

2 United Nations Development Program, International Policy Centre for Inclusive Growth, Poverty Practice, Bureau for Development Policy, Poverty in Focus: Indigenizing Development, No. 17 (May 2009).

3 Follow-up to the recommendations of the Permanent Forum: indigenous women, United Nations Economic and Social Council, New York (2009).

(C) OOSTERHOFF, PEETERS AND HONDERDO, 2015 | DOI 10.1163/9789004282087_015

This is an open access chapter distributed under the terms of the prevailing CC-BY-NC License at the time of publication. 
differences is important, and can contribute to a more complete and accurate picture of rich indigenous cultures, but it can also be seen as divisive and threatening to already marginalized populations. The ethical perils and moral burdens that face outsiders who try to represent diversity and change within marginalized indigenous cultures through art have been extensively debated, in particular by critical visual anthropologists. ${ }^{4}$ Cultural anthropology as a discipline assumed that an "outsider" could objectively describe and explain a culture from the insider's point of view. Ethnographic film was a way to 'record' and explain the native's perspective. Anthropology should enable Westerners "to see the world through the eyes of the native" (Malinowski 1922).

But this ability to represent others has been seriously questioned by a range of actors including indigenous filmmakers who want to take charge of this representation process. A common problematic representation of indigenous cultures by outsiders in film and photography is a victimizing, tragic portrayal of "disappearing" cultures facing extinction via contact with the "western" or "developed" world. Another is the romantic portrayal of "stone-age cultures" that have been untouched by development. Such problematic iconizations of the heroic indigene have been with us ever since George Catlin's 19th-century paintings of noble Native Americans and the partially staged dramatic sequences of Inuit life in Robert Flaherty's Nanook of the North. Both the romantic and the tragic portrayals of indigenous peoples are variations of essentialist "othering" by outsiders that fail to recognize indigenous cultures' internal diversity, their long history of participation in the global market economy, and the aspirations and abilities of indigenous individuals to improve their own lives. One approach to address the problems associated with outsiders representing indigenous cultures has been to work on art projects in a more participatory fashion with indigenous communities. Representatives of indigenous communities, it is hoped, can provide a more complicated and realistic insider's portrayal of their community. This view of authorship, where only insiders can describe a culture accurately, is also essentialist and raises some old and thorny questions about the abilities, rights and responsibilities of artists to create works above and beyond their personal identities and lives.

This article deals with two participatory community art projects exploring aspirations and fears regarding identity and development with representatives of indigenous Benet peoples in Uganda and Khasi peoples in India. The projects were implemented in collaboration with Dutch artists as well as development and museum experts from the Royal Tropical Institute, Amsterdam, in

4 J. Ruby, "The moral burden of authorship in ethnographic film," in Visual Anthropology Review, Volume 11, Number 2 Fall (1995). 
2012. The development experts worked for over a decade on indigenous wellbeing and are part of a global network of development practitioners, activists and indigenous representatives. Through these contacts a number of indigenous groups in Asia and Africa were identified that experienced clear tensions between cultural heritage preservation and development. One key consideration was the availability of a variety of local leaders and organizations, especially indigenous ones, who understood and supported a collaborative artwork on indigenous identity, aspirations and fears. Another was community access to basic necessities such as drinking water, physical safety, and electricity for computers. The first selection of five groups was made through desk research and interviews, followed by field visits by experts to discuss the project in person and show examples of other joint projects and installations. Some potential communities visited, such as the Maasai in Kenya, expressed great interest, but lacked sufficient food and water even for their own needs. Hosting artists to live with a family on a compound and having to share their scare resources would have been a serious burden. Trucking resources such as water, food and electricity in, could also create tensions and we decided against it for ethical reasons.

\section{Indigenous Peoples, Cultural Heritage and Development}

Indigenous peoples are a heterogeneous but significant group that number 370 million and live mostly in Asia, Africa and Latin America. ${ }^{5}$ They make up an estimated third of the world's poorest "bottom billion," with poorer health outcomes than the majority populations or as Stephens et al. (2005) have put it indigenous peoples are "behind everyone, everywhere." They are key stakeholders in international development cooperation and debates. However, in practice indigenous voices and issues are often still invisible. In some cases the very use of the term "indigenous" is avoided, which makes it hard to know who are indigenous groups or how many members they have. India does recognize indigenous rights but the government frequently refers to indigenous people

5 See 1.United Nations Department of Economic and Social Affairs, State of the World's Indigenous Peoples (New York: United Nations 2009) or United Nations Permanent Forum on Indigenous Issues. Who are indigenous peoples? Accessed August 12, 2013. <http://www.un .org/esa/socdev/unpfii/documents/5session_factsheet1.pdf> or Department of Economic and Social Affairs, Division of Social Policy and Development, Secretariat of the United Nations Permanent Forum on Indigenous Issues (UNPFII). State of the World's Indigenous Peoples (2009). <http://www.un.org/esa/socdev/unpfii/documents/SOWIP_web.pdf >, visited on 12 August 2013. 
under the terms "scheduled tribes" or "Adivasi." These local terms do not have the same international legal status and recognition, and unless one already knows the local terms it would be hard to research indigenous peoples even in English language texts.

In other countries such as Indonesia or Botswana, the word "indigenous" is no longer employed at all, or only for very small groups, because the term has legal connotations with regards to land rights. In Indonesia many terms have been used to describe their communities since independence, including native people, adat communities or adat law communities, and isolated people. These communities are often displaced from their land for the implementation of development projects in sectors such as forestry, mining, and agriculture, such as palm oil plantations on Kalimantan, the home of many peoples who were previously considered indigenous. (Myrna Safitri and Rafael Edy Bosko 2002) In Botswana the San, who are recognized by the UN and African organizations as indigenous peoples are not recognized as such by the government. In 1966, the government has adopted a 'non-racial' policy at independence and holds that all citizens of the country are indigenous. Claims of the San to their native lands are dismissed.

Indigenous land rights, both individual and collective, are violated in many countries. Such land rights are recognized by numerous international statutes, including the Indigenous and Tribal Peoples Convention of 1989 ("ILO 169"), the Declaration on the Rights of Indigenous Peoples, the Convention on the Elimination of All Forms of Racial Discrimination, the International Covenant on Civil and Political Rights, and the American Convention on Human Rights. Indigenous peoples can claim land rights from national governments using these laws, including land that has valuable mineral resources.

For ethnographic museums, the mission to preserve and support the cultural heritage sector has all too often led to essentialist misrepresentations of indigenous cultures as "traditional" or "endangered" by development or resistant to change. The critical study of the social role and impact of museums that developed in recent decades has suggested that engagement with the concepts of social inclusion and exclusion will require museums - and the profession and sector as a whole- to radically rethink their purposes and goals and to renegotiate their relationship to, and role within, society (Sandell 2003: 45). Nowadays, there is consciousness that museums have been linked to nationalist, modern and majority-culture discourses, neglecting diversity and excluding indigenous peoples and other minorities in shaping the social agency of the museum. Sandell (2002) argues that museums as social institutions have the ability to promote collective action and potentially empower individuals and communities towards social inclusion. There is also more awareness that 
the distinctions between traditional and modern are not clear-cut; individuals can be both traditional and modern. In addition there is wider recognition of the importance of individual agency in shaping and responding to wider changes.

Appadurai (2004) argued that cultural preferences for global cultural products may not just be a sign of the loss of 'traditional' culture but rather reflect the capacity of individuals to aspire to a different and better life. Aspirations are a hybrid mix of choices expressing multidimensional, many-faceted and socially embedded capacities and hopes to improve life. Aspirations can be complementary or may substitute each other. For example, young Hmong, an ethnic minority group in South-East Asia, use their mobile phones to listen to radio programs made in the United States or Australia by overseas Hmong broadcasting in the Hmong language. They embrace both traditional and modern cultural customs and consider themselves as new transnational citizens. Rather than lamenting the loss of traditions, there is a need to examine more complex ways to represent cultural heritages that are both more accurate, and recognize indigenous cultural and development aspirations in a global world.

In order to understand what these aspirations might be it is necessary to listen to and involve indigenous peoples. A more inclusive engagement and representation of marginalized groups and their aspirations in both development and cultural settings require some form of enhanced participation. Indigenous critical collaborative and participatory productions are not new, as evidenced by audiovisual productions such as "Through Navajo eyes" (1962) and the Brazilian "Videos in the Villages" of Vincent Carelli (1993). However, the need for participation is today more widely recognized and supported by development and cultural practitioners, national governments and donors.

\section{Participatory and Community-Based Art Projects}

In the last decade there has been a surge of participatory and communitybased art projects all over the world, including in the Netherlands, where they continue to grow in spite of budget cuts for the arts. Under the flag of community art, a broad range of project sail that differ greatly in form, content and aim. But they have one thing in common: they create a bridge between art and society (Twaalfhoven 2010: 4).

Many well-known organizations such as PhotoVoice explicitly aim to empower invisible or marginalized communities and use (digital) photography as a tool to make their views and concerns visible to (remote) policy makers or donors. PhotoVoice aims to build skills in disadvantaged and 
marginalized communities so that they can represent themselves and achieve positive social change through the use of participatory photography and storytelling methods. Such positive social change can include recognition of their individual talents as storytellers or attention for their issue by authorities that have ignored them.

How should these community art initiatives be judged? Should they be judged as artworks, as contemporary history writing, as popular heritage preservation or as civil society engagement? Nicolas Bourriaud, a French art critic who explores the rise of interactive art, argues that the public wants to get closer to the artists' thoughts and work. The process of emotional, intellectual and physical interacting of the public with artwork and with the artists is a process of "relational aesthetics." (Bourriaud 2002) Relational aesthetics include the desire of the public to have interpersonal connections and relations with the art, not just an aesthetic appreciation. And it is in their ability to engage people with both the artwork and the artist in new ways that their public, civil value should be sought.

Community artworks invite citizens to be involved in the artwork, providing new opportunities and modes of engagement for artists. In addition, they appeal to politicians at a time when the state's role in the social sector and the arts is receding, and they cater to the more interactive demands of today's consumer-oriented citizen. Yet two important questions in these interactions are the following: who is the community and who participates? Mansuri and Rao argue that the term "community" in the literature on development is frequently used without much qualification "to denote a culturally and politically homogeneous social system, or one that is, at least implicitly, an internally cohesive and more or less harmonious entity" (Mansuri and Rao 2003:10). In reality the definitions of a community geographically, culturally or conceptually can be complicated. How do (semi) nomads or rural (seasonal) migrant workers for example, fit into an administrative community? If one "targets" nomads through allocating resources in an administrative zone based on their presence when the administrator is there they might literally not be there when the resources arrive. Targeting semi-nomadic peoples as a cultural entity could potentially avoid that issue but may obscure local structures of power. Power relations matter at the level of the community, between the state, artists and communities. Some groups or individuals have a bigger voice than others. When power inequities within and between communities are not recognized, the participative process can be hijacked by local elites. When one works with indigenous peoples on community art it is therefore important to avoid romantic harmonious views and critically reflect on what community and representation mean in that specific cultural context and society. 


\section{The Project: Visualizing Development with Identity}

The authors of this article have been involved in international development and community art projects for two decades, including several projects with minority ethnic and indigenous groups. In this article we reflect on two recent joint projects with indigenous Benet peoples in Uganda and Khasi peoples in India in 2012.

These projects were undertaken as part of a collaborative initiative, "Visualizing Development with Identity," between an ethnographic museum, a library, and development experts at the Royal Tropical Museum. The lead author was the project leader and the two artists worked with communities on the production of installations, soundscapes and film productions that examined and countered stereotypes of indigenous people. This team hoped to enable indigenous people to create installations and soundscapes that visualize and articulate their diverse views and aspirations on culture, development and identity, as well as to establish collaboration with local universities, indigenous artists, museums and galleries. As clearly visible outsiders to these indigenous cultures, we were faced with many moral and practical dilemmas with regards to authorship, ownership and participation in the process of developing these projects. Both communities are globally recognized as indigenous communities with strong links with their ancestral lands and the forests. We will use these cases to explore whether and how collaborative production of art installations with representatives of indigenous groups can provide alternatives to "traditional" cultural stereotypes of indigenous peoples and their relationship to national development initiatives. We will also discuss what participation, community and empowerment could mean, and hope to make some contributions on the question of how to assess the impact and effectiveness of such projects.

\section{The Red, Gold and Green of the Khasi, Meghalaya, India}

The Khasi are an indigenous matrilocal and matrilineal group of around 1.2 million people, mostly living in eastern Meghalaya, a state in northeast India. ${ }^{6}$ India has an indigenous population of 98 million, almost a quarter of the world's indigenous population, most of it residing in the northeastern part of the country.

6 These are official estimates from the Census of India. Actual numbers are not known. 
The Khasi make up the majority of the state's population. They hold important government posts, UNESCO has recognized their language, and there are Khasi newspapers, as well as a rich Khasi-language literature on different aspects of their culture and on the environment. The Khasi, both men and women, are doing well in many regards compared to other indigenous groups. However, compared to mainland India, their health and economic status is poor. ${ }^{7}$ The area is one of the most ecologically diverse forested areas in the world (Chatterjee et al. 2006). There are over 50 sacred forests, which are at the heart of Khasi culture. The close relationship of the Khasi with the forest has resulted in unique cultural skills, such as the construction of bridges woven from living tree roots. The forests are rapidly being destroyed by mining and other development activities.

In preparing for the art project, in both the Netherlands and India, we implemented a participatory action approach and methods that closely resemble the participatory rapid appraisals (PRA) used in development projects, such as mapping and ranking in focus group discussions. We conducted a literature review, and discussed with Tropical Museum staff the feasibility and methodology of exhibition-making for museums in indigenous societies with few material artifacts. Prior to the arrival of the artists in the indigenous communities, the project leader visited the project host, a university in the Meghalayan town of Shillong, to discuss the plan. She also conducted participatory observations in villages and in the city, and met with various stakeholders, such as healers and journalists. The artists continued this research and conducted several weeks of participatory observation in urban centers and villages. They gave in-depth presentations of earlier work to media representatives, traditional healers and students; they interviewed leaders and gave hands-on trainings to local artists. These methods provided insight on the key themes related to identity and development according to these Khasi representatives, and on the availability of cultural artifacts to visualize these themes.

It soon became rather clear that there are significant differences of opinion among the Khasi about what development with identity means. Young urban people, for example, connect and identify themselves with both Khasi culture and global rap culture; they did not report contradictions between being a Khasi, using mobile phones, and listening to rap or pop music over the Internet. Other, older stakeholders, however, viewed global culture as a threat to Khasi culture and identity.

7 See for official estimates on such inequities for example: NF HS-3. International Institute for Population Sciences (IIPS) and Macro International. In National Family Health Survey (NFHS3), 2005-06: India: Volume I. (Mumbai: IIPS, 2007). 
As a result of these very different views on what Khasi identity means, four distinct yet interrelated projects emerged: a short video documentary on Khasi herbal healers, a rap production on alcohol abuse with three young Khasi artists, a three-dimensional installation with a soundscape, and a festival to launch the installation with poetry and Khasi musicians working in different musical traditions. This allowed different voices to express their views on development with identity. For this article we will focus on the installation, as this was the focus of the project in both Uganda and India.)

The installation consists of four 'rings' in which each of the seven elements (referring to the Ki Hynñiew trep, the seven Khasi tribes) represent a particular aspect of Khasi social relations. The lowest circle of large baskets represents the "gold" of the Khasi, the natural resources: rice, bamboo, limestone, shriew (a local root vegetable), coal, betel nuts and medicinal herbs. This installation and the soundscape thematically interweave the ways that global and local indigenous cultural elements simultaneously support and undermine contemporary Khasi culture.

The second upper circle of cone-shaped baskets represents key aspects of the Khasi spiritual cultural heritage: language, matrilinearity, music, sacred forests, ethics, beliefs and rituals and herbal healers.

The outer circle consists of local rain shields (knup).

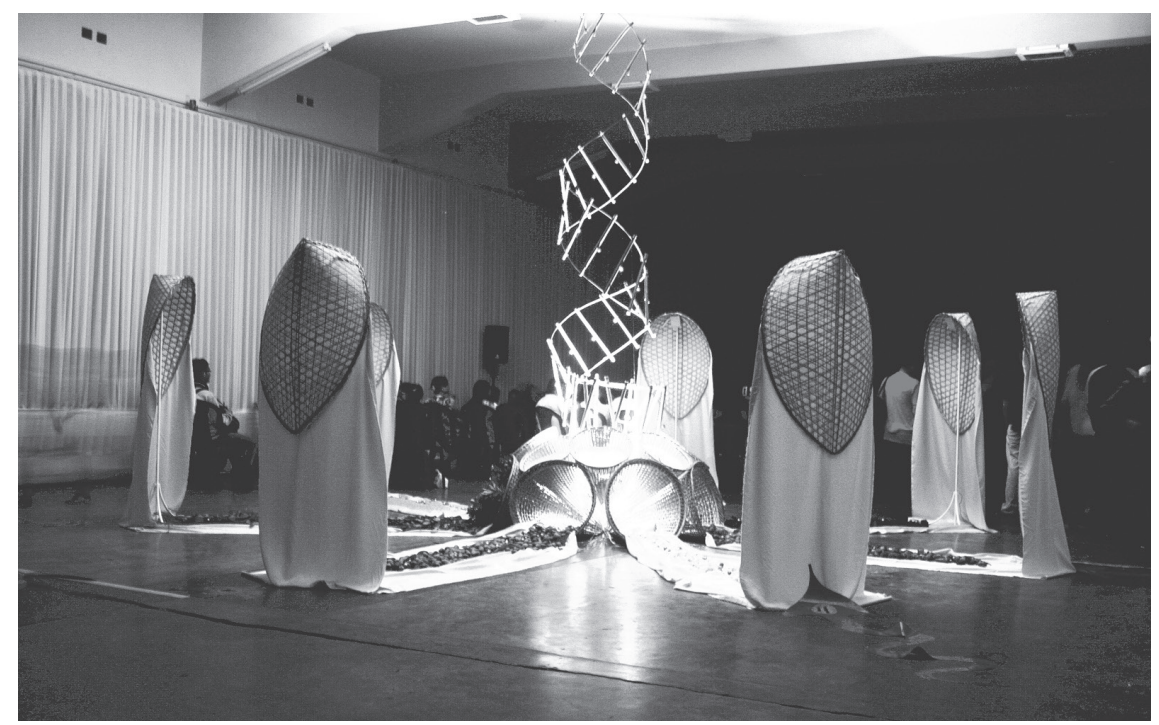

FIGURE 1 Overview shot of the installation "The Red, Gold and Green of the Khasi" 


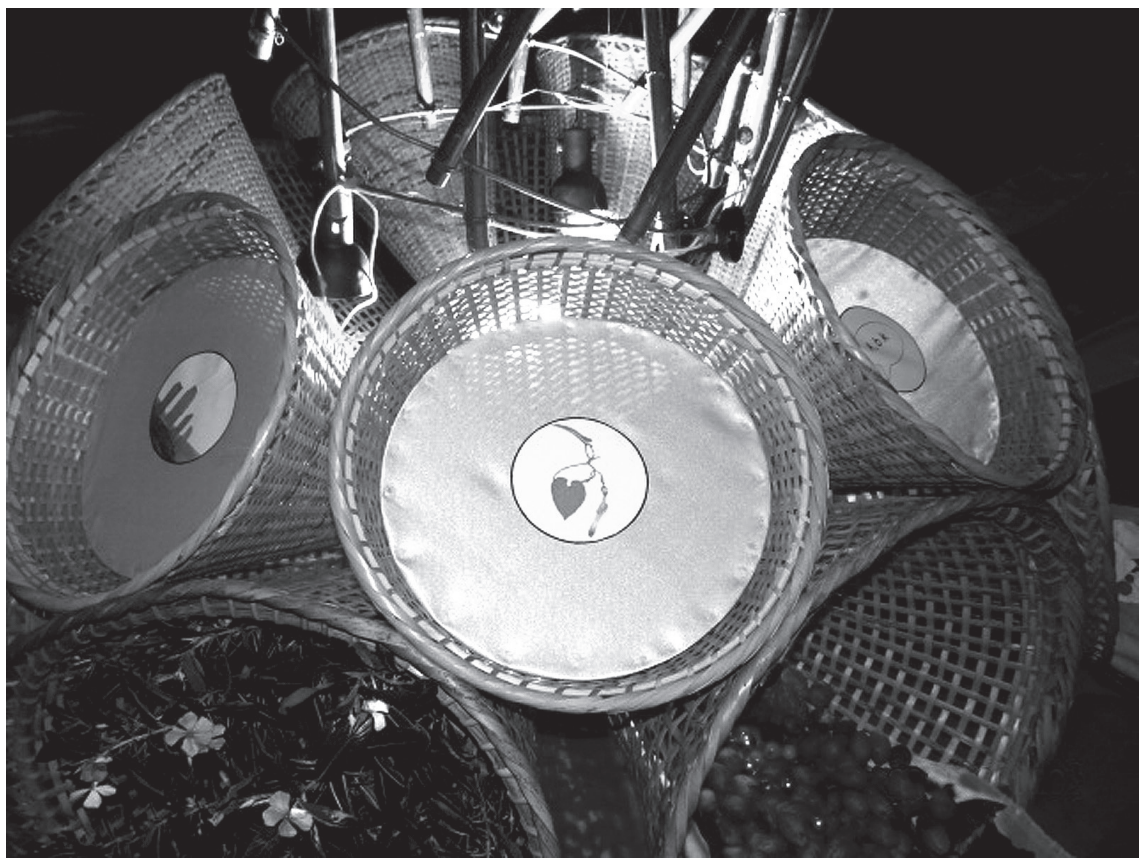

FIGURE 2 Close-up of the installation "The Red, Gold and Green of the Khasis"

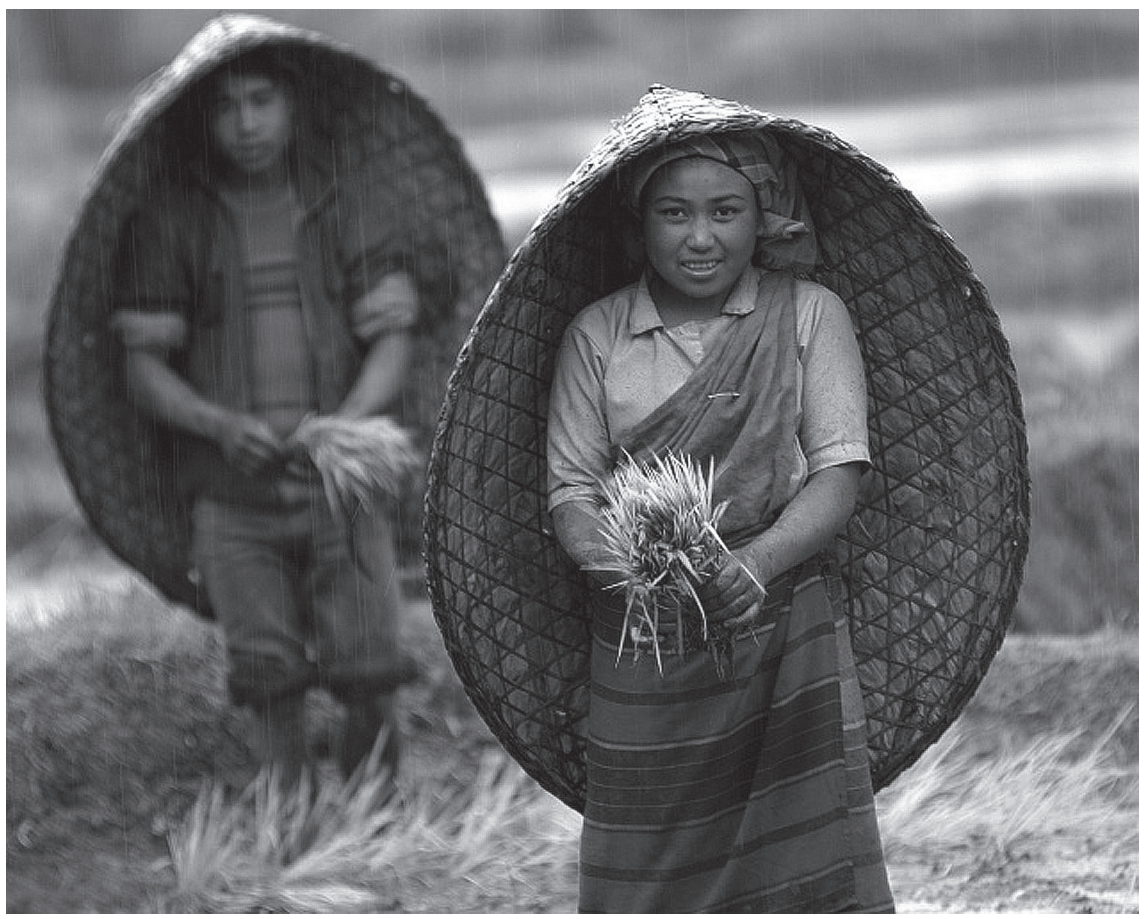

FIGURE 3 Khasifarmer women with traditional umbrellas 
At the bottom, a circle of serpents depicts the dangers that threaten Khasi culture and identity: alcoholism, the influx of foreigners, corruption, pop culture and $\mathrm{TV}$, urbanization, religion and pollution.

The soundscape consists of voices (sound) summarizing the visual information coming from 14 loudspeakers that are mounted inside the baskets and the

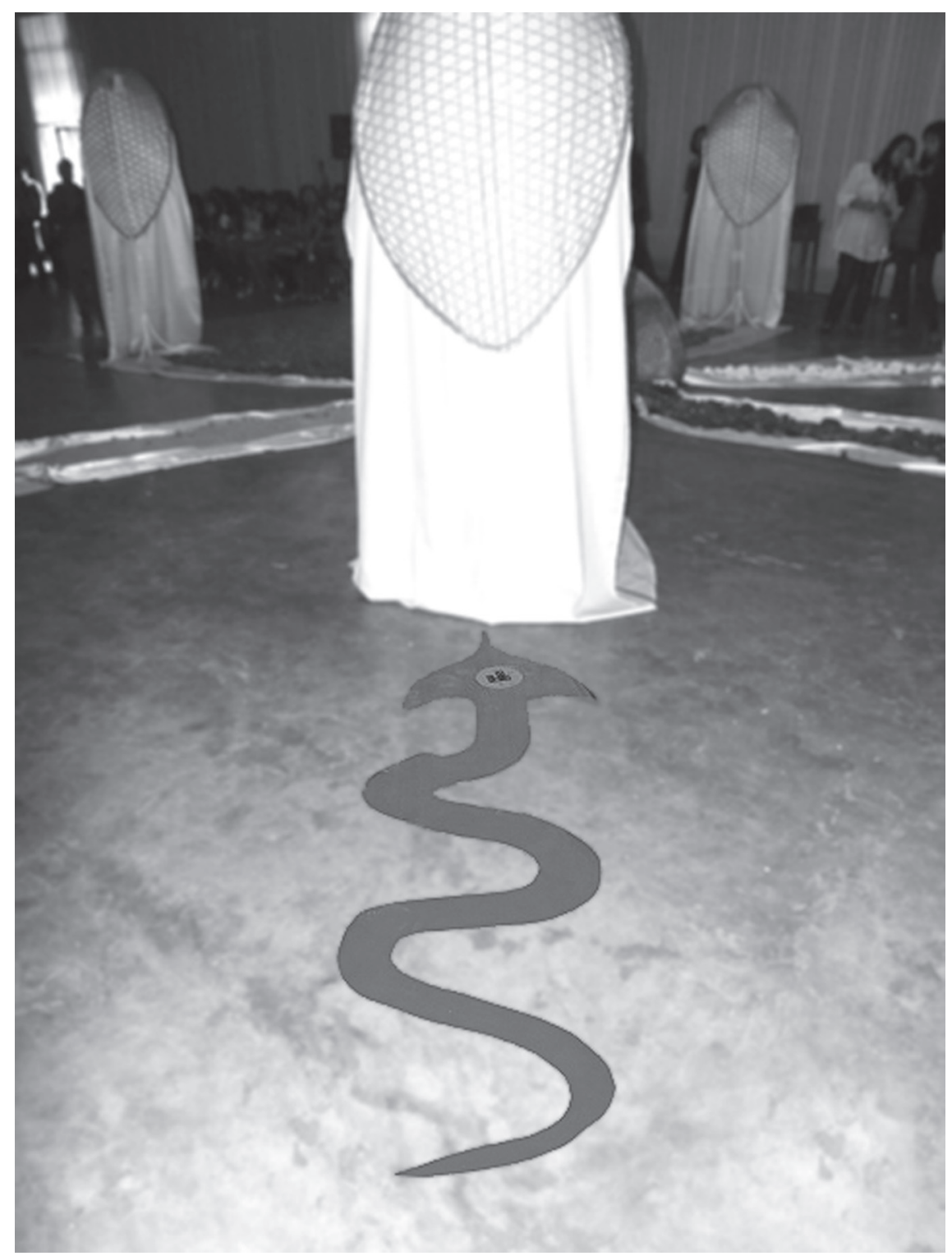

FIGURE 4A Traditional Khasi umbrella in the installation 


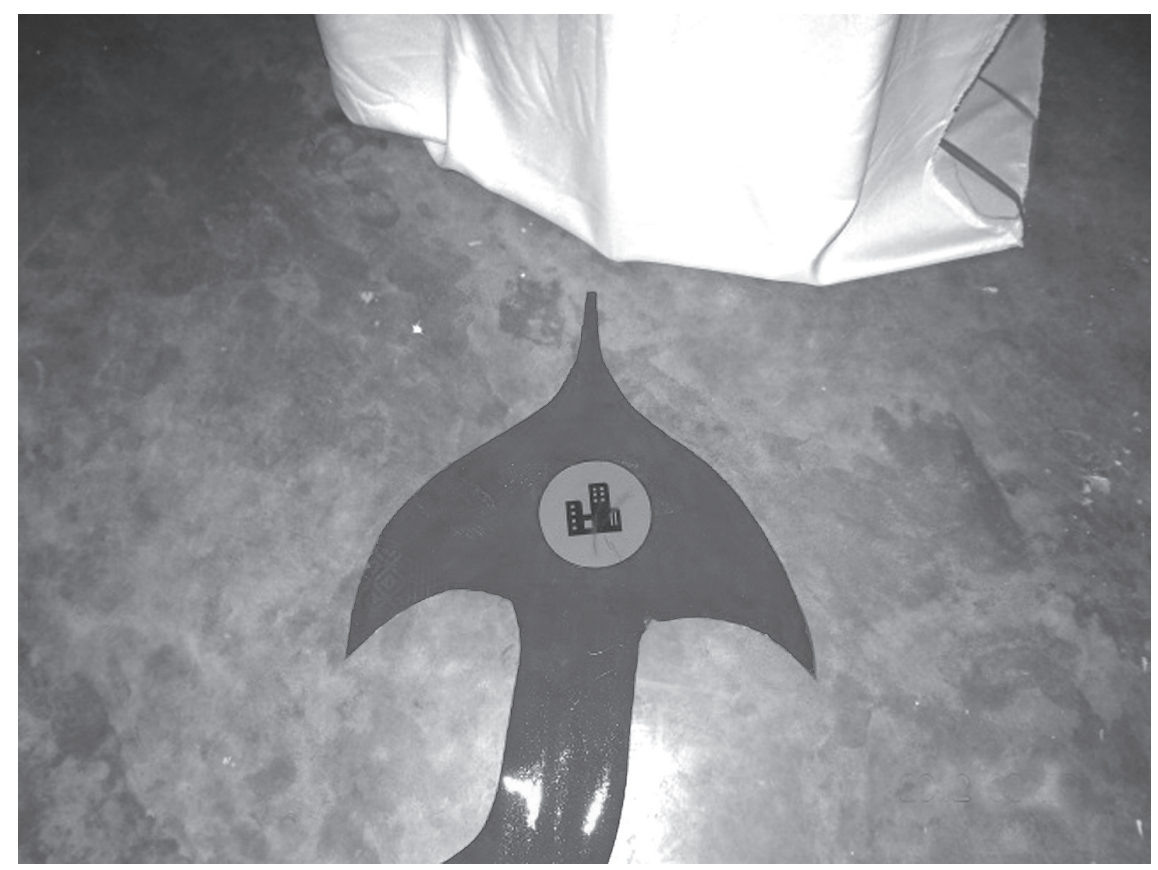

FIGURE 4B Serpent as a threat to Khasi culture

rain shields, creating a spatial dialogue between them. Also, sounds from the sacred forests and Khasi ritual drumbeats can be heard.

In the center of the installation a rope ladder goes upwards. This refers to the Khasi legend of Jingkieng Ksiar, a golden rope ladder on U Sohpetbneng (the mount of the heavenly umbilical cord), from which the tribes would descend from heaven. They would labor all day and cultivate and reap profits from the land. Then each evening they would return by the same route. ${ }^{8}$ This golden ladder was severed when sin crept into the world. As a consequence of the severance, nine families remained in their celestial abode and seven settled on earth and multiplied. The ladder also resembles the double helix of DNA, linking biological and spiritual identity markers.

The installation and its presentation were attended by hundreds of people from different backgrounds, mostly from Shillong and the surrounding area.

8 See for more details on this legend for example: Sawian, Bijoya, Khasi Myths, Legends \& Folk Tales (New Dehli: Sanbun Publishers, 2010) or Das, Manosh, A Khasi pilgrimage to 'heaven's navel on earth (Times of India, Feb 6, 2012). <http://articles.timesofindia.indiatimes.com/201202-o6/guwahati/31030049_1_umbilical-cord-earth-huts>, visited August 122013. 
It received positive press reviews on the front pages of seven state newspapers and on social media from indigenous journalists and leaders. The installation is now permanently hosted by the Don Bosco Ethnographic Museum, the largest ethnographic museum in northeast India. The museum provides information on all the tribes in India's northeast through the display of sculptures, artifacts, films, and computer-based interactive narratives.

\section{Rooted, an Installation with the Benet People in Kapchorwa, Uganda}

The Benet are a small, little-known indigenous group in Uganda living on the margins of society on the slopes of Mount Elgon, near the Kenyan border. It is estimated that the Benet number about 20,000 people. ${ }^{9}$ They are culturally related to but distinct from the Sabiny. ${ }^{10}$ The Benet were initially pastoralists who also hunted and gathered. They may have resided in the forests of Mount Elgon for over 200 years, escaping cattle rustlers from the plains. The Benet sometimes refer to themselves as Mosopbishek: people who live on the mountain.

In 1993 the Ugandan government declared Mount Elgon a national park, dispossessing the Benet of their land. The creation of the park was accompanied by physical violence against the Benet, as well as continuous marginalization by the state bureaucracy. The Benet were excluded from development in and around the area (infrastructure and healthcare), yet they still had to pay taxes. In 2005 they successfully instituted legal action against the government of Uganda, alleging that they are the historically indigenous inhabitants of the land around Mount Elgon, which entitles them to stay. In spite of pressure from local and international NGOs and lobby groups, and several in-depth studies of the land issue, the situation of many Benet remains uncertain.

The infrastructure in the small communities where the artists worked with the Benet people is very poor, with muddy roads, little to no access to electricity. And even in Kapchorwa, the local capital where the artists stayed and worked mostly, resources are tight. This poses challenges for the use of equipment for research, documenting, sketching, editing or composing. Illiteracy rates are high, and many Benet are very poor. However, the Benet

See: IWGIA - The Indigenous world (2007) The Horn of Africa and East Africa. <http:// www.forestpeoples.org/documents/africa/uganda_iw_2007.pdf>, visited on 10 April 2008. 
people encountered during this visit made a clear and articulate analysis of the installations that the artists had put together with other communities in other countries, such as with HIV-positive women in Vietnam, and how they could apply these collaborative art techniques.

The artists conducted additional participatory observations in villages around Mount Elgon and met with Benet leaders as well as politicians. From these interactions it became clear that the sense of identity among older Benet is shaped to an important extent by their displacement from their ancestral land. Outsiders like NGOS and researchers may have reinforced this focus on displacement in their interactions with the Benet. When projects and research explore a certain topic, such as land rights, other issues such as musical culture, oral history skills and the views of the younger generation receive less attention. Nowadays, they employ few artifacts that might represent a traditional material culture, and little performative culture (songs or dances) is presently performed or shared with the younger generation. This does not mean that Benet have "lost" their culture, but there is a change in the production of material cultural artefacts.

In this installaition, The Benet's different views of their identity were integratd in one installation with four distinct elements: inscribed sculptures of trees and baskets, uprooted seedlings, children's drawings and an accompanying soudscape.

The sculptures of trees and baskets visualize several key themes of ancestral heritage that lie at the heart of Benet identity.

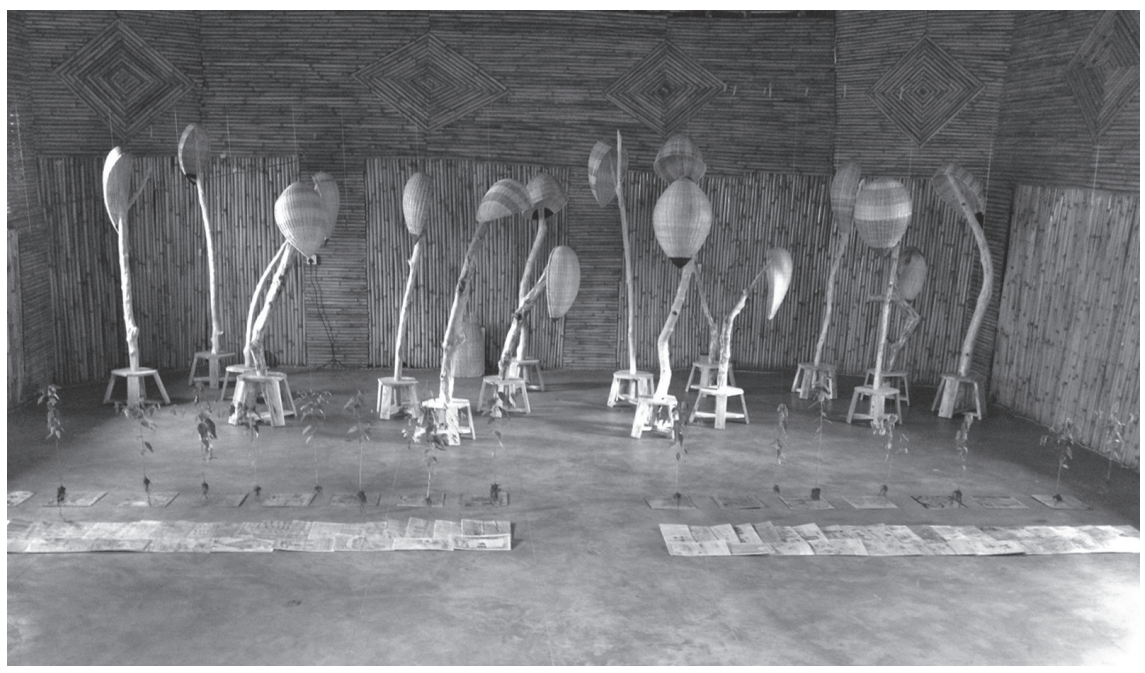

FIGURE 5 "Rooted" installation overview; inscribed sculptures of trees and baskets 
The sculptures obviously refer to the forest, but the "trees" are grouped four by four: a spiritual numerical value within Benet society. For example, during the circumcision ritual, a boy must run around his hut four times before the operation can take place. The tree poles, normally used to build huts, crop-containers and fences, have the names of deceased Benet written on them. The names have been chosen by Benet elders and spokesmen, and are written in their original Kupsapiny clan-form, which makes them directly identifiable to local Benet.

The baskets refer to the ancient trade relations between the Benet women and outsiders, exchanging baskets for money or food. A basket could be exchanged for the amount of maize, wheat or rice it could hold. Traditional Benet basket weavers wove specific baskets for this installation. These baskets are also arranged in four separate groups: healers (green "dipped" baskets), elders (white), jusdges (black) and victims of the evictions (red).

The second element of the installation consists of tree-seedlings. These have both a negative and positive symbolic connotation. Planting trees is intended to "contribute" to the National Park. By contrast, clearing trees from one's land to make way for individual cultivation has become a way of resisting the park and marking the land as an individual's property. ${ }^{11}$ Yet planting trees is also a necessity for soil conservation (to avoid landslides). Planting trees means investing in the future, and hence implies trust that the planter can keep their land in the future. The seedlings are hanging just above the floor, so the roots cannot reach the soil. They symbolize longing and doubt as to whether to hold on to the past or invest in the future. The third element examines the linkages between the past, the present, and the current situation through children's eyes.

These children's drawings on plywood parts $(25 \times 25 \mathrm{~cm}$ and $30 \times 15 \mathrm{~cm})$ portray the small plots of land dotted on the slopes of Mt. Elgon and the futures the Benet children living here have envisioned. There are drawings of the animals they have, what they want to be in the future, what they would buy if they had 10,00o Ugandan shillings, and what they would grow on their lands. The line behind the seedlings represents the situation as it once was: enough land was there to herd the cattle, which is why this line of drawings is neatly spaced. The line in front of the seedlings, however, depicts the lack of land: everything is piled up. The three elements together represent the widely shared idea that intensified agriculture and more land are needed to supply the growing population, in addition to education, which can help the children to secure different

11 This reasoning has been examined in detail by David Himmelfarb in his $\mathrm{PhD}$ thesis In the Aftermath of Displacement: A Political Ecology of Dispossession, Transformation, and Conflict on Mt. Elgon, Uganda. (University of Georgia, Athens, GA). 


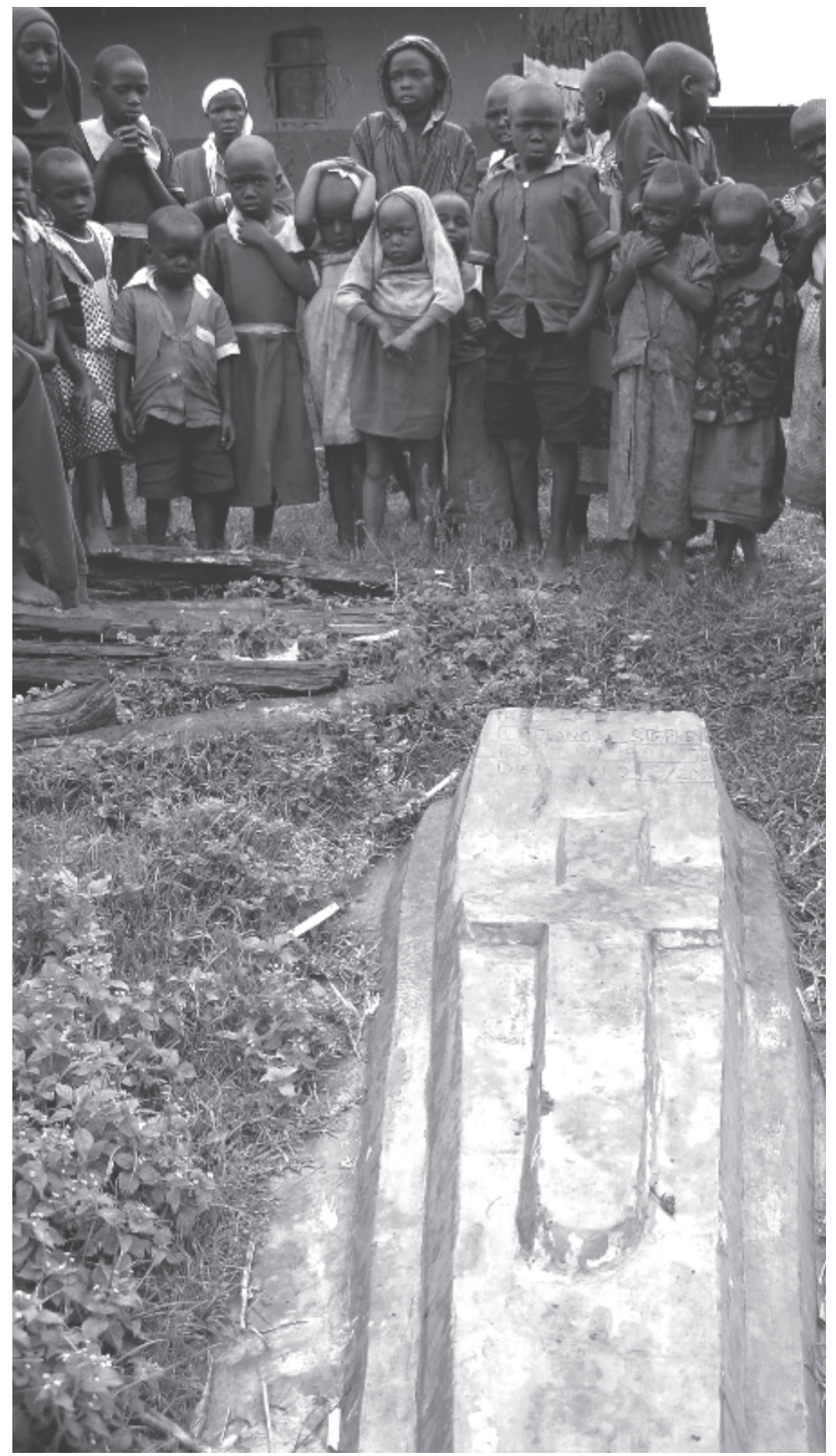

FIGURE 6 UWA rangers killed Chelangat Saima and his brother, when they were grazing their cattle inside the park boundaries. 


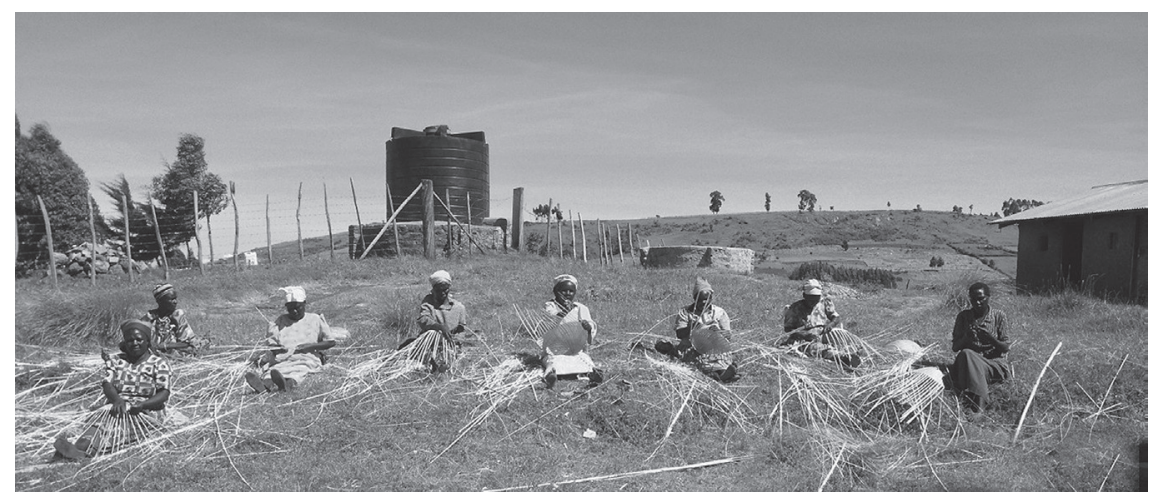

FIGURE 7 Women in the village of Mengya, weaving baskets for the installation

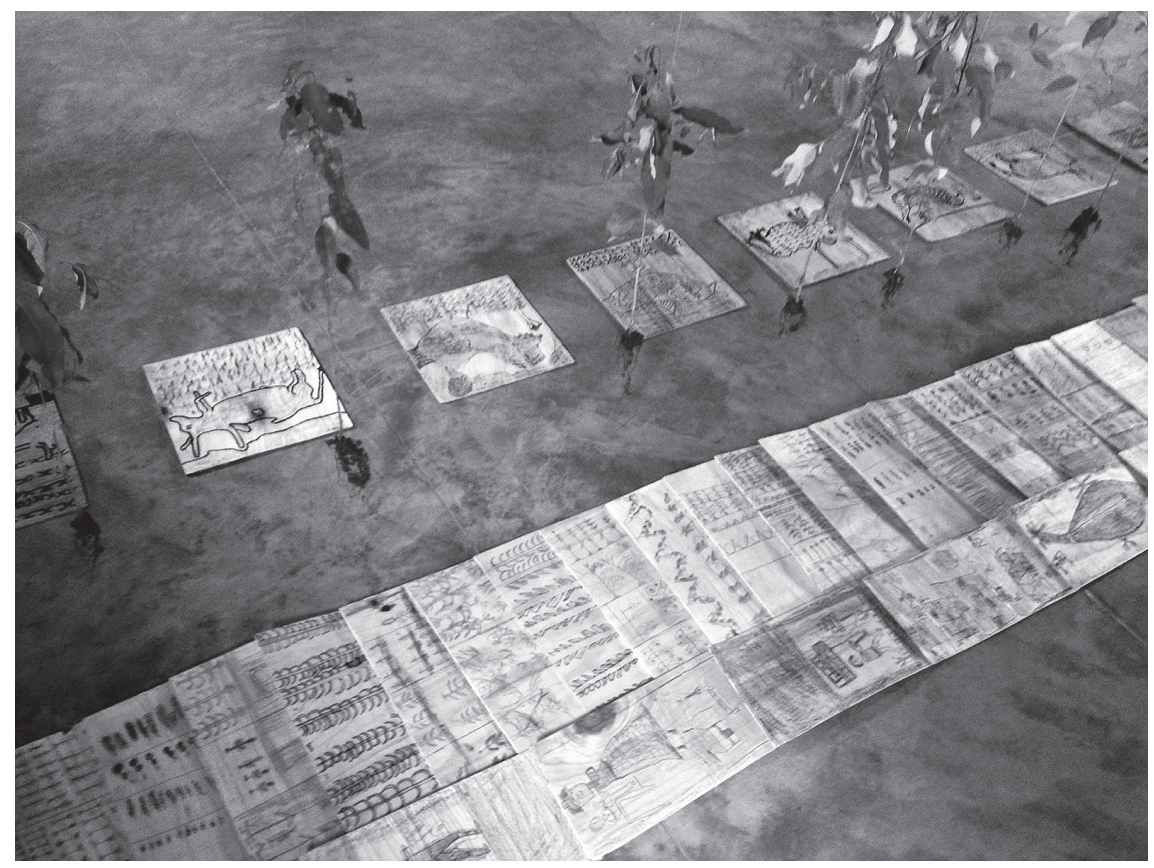

FIGURE 8 Uprooted seedlings and children's drawings

professions as adults. A soundscape composition that accompanies the installation consists of environmental sounds that were recorded inside Mt. Elgon Forest (cicadas and crickets, birds, streams and bees), interwoven with the voices of elders and women speaking about life in the past, and of children voicing their future plans and dreams. Traditional forest instruments and songs accompany these recordings. 
The presentation of the installation in Kapchorwa was a success, with most attendants being Benet, some of whom had never travelled outside their parish before. Dozens of dignitaries also attended: politicians, community leaders, and representatives of civil society. The installation provided a unique opportunity for the Benet to represent themselves and become visible to local leaders. Reviews in the written press, TV and online were positive, describing the exhibit as a new way of addressing social issues through art. The installation subsequently travelled to Makerere University in the capital of Kampala, accompanied by Benet participants who explained the project to students, staff, visitors and press. It will ultimately be hosted in the Benet Cultural Center, currently under construction in Mengya. For the Benet the production of the installations and their launches provided a way to engage with local politicians and citizens, and to present their history, their culture, and their aspirations in a positive and aesthetic fashion.

\section{Reflections on Participation, Power and Relational Aesthetics in Indigenous Community Art Projects}

These two collaborative art installations, in which a display of daily artifacts narrates a multi-faceted story provided by indigenous local community representatives, differed sharply from previously existing portraits and narratives of the communities they represented. Both installations interweave disparate community voices and concerns regarding identity and development into a coherent whole, and discuss this narrative with both insiders and outsiders. But their complexity, a result of local participation, also renders them very difficult for outsiders to understand without local interpretation. When artworks are made for and by a local population, their significance may be hard to grasp for outsiders, for whom the choice of four rather than seven or a hundred trees for the sculptures of trees and baskets seems rather arbitrary.

The installations do not claim to speak for all Benet or Khasi. Those who participated and were able to voice their views were mostly formally educated or occupied important positions in local society - healers or traditional leaders, local businessmen and teachers - speaking on behalf of the uneducated. Although the Benet and Khasi are different in many ways, both installations visualize complex aspirations and fears in relation to the preservation of cultural identity and heritage, and in both, the disappearance of forests and ancestral lands in a globalizing economy plays a key role. In both installations, the views expressed on how to integrate development with identity are hybrid and contradictory. They reflect a desire to be grounded rather than uprooted, 
and to be connected to a larger global whole. Children want to master the English language, to complete formal education, to become teachers or policemen, to promote justice and improve the current situation. In Red, Gold and Green, coal is both a natural resource and a cause of pollution and the destruction of sacred forests. Also, it drives an illegal influx of low-wage labor, with all its associated problems.

In Rooted children express their desire to settle and study, yet permanent settlement is also problematic for pastoralists. The trees themselves have become markers of globalization for the Benet; natural reserves create new categories of insiders and outsiders with respect to natural resources. The meaning of planting a tree varies according to its location. It is different in a local space (such as a garden) than in a national or global space (such as an internationally funded nature reserve).

What can we say about the contribution such initiatives make towards indigenous people's efforts to integrate globalization and development with identity? First, the projects helped the Khasi and the Benet to give concrete form to economic and cultural desires and anxieties that had often remained vague or unvoiced. The participatory work method motivated large audiences of young and old indigenous people, in communities that do not normally visit art galleries or ethnographic museums, to attend the presentations. The projects were a channel for indigenous people to become objects of knowledge for themselves, and to become the producers of that knowledge. While the artists were outsiders and the initial work was financed internationally, the costs were low: the total budget for two installations (including its presentations), a music video and two short documentaries was 68,00o euros. Just as important, both installations are now hosted by local institutes and maintained with local funding, suggesting that the ongoing impact if not the initial jump-start is sustainable.

The production of the installations employed indigenous artisans and artists, and in both contexts there was a wide diversity of stakeholders who provided input to the artworks. Some local artists received training in installation-making. Such participation does not necessarily imply any significant boost to economic development or political empowerment. However, the projects mobilized and organized indigenous people, cemented established relationships and developed new ones between artists, participants and audiences.

The value of these art projects might therefore best be seen in terms of relational aesthetics: the capacity to involve citizens in studying and representing themselves, to reflect on the right to development with identity in a globalizing economy, and to provide new opportunities and modes of engagement for 
local and international artists to work with indigenous people and help them visualize their aspirations and concerns.

\section{Acknowledgements}

This Interdepartmental Collaboration project at the Royal Tropical Institute (KIT) has been funded by DGIS. The authors are particularly thankful for the support and input of KIT staff, notably Anke van der Kwaak, Itie van Hout, Richard van Alphen, Tilly Minnée, Wayne Modest and Ilse Eggers. In India, special thanks are due to Glenn Christo (MLCU), Sandra Albert (London School of Hygiene \& Tropical Medicine), Alka Kharsati (traditional healer), Patricia Mukhim (Shillong Times) and SPIKAP.

In Uganda we would like to thank Moses Mwanga, Moses Kiptala, Elizabeth Kwagala (MU) David Himmelfarb (University of Georgia) and Aggrey Kibet (ActionAid Uganda).

We would like to thank Matt Steinglass for editorial input and advice.

\section{Bibliography}

Appadurai, Arjun. "The capacity to aspire: culture and the terms of recognition," in

V. Rao and M. Walton (eds.), Culture and Public Action. Washington, DC: The World Bank, 2004: 59-84.

Bourriaud, Nicolas. Relational Aesthetics. Paris: Presses du réel, 2002.

Brooks, T.M.; Mittermeier, R.A.; da Fonseca, G.A.B.; Gerlach, J.; Hoffmann, M.; Lamoreux, J.F.; Mittermeier, C.G.; Pilgrim, J.D. and Rodrigues, A.S.L. Global biodiversity conservation priorities. Science 313, 2006: 58-61.

Census of India, Meghalaya Data highlights: The Scheduled Tribes. Office of the Registrar General, India, 2001.

Chatterjee, Sudipto, Abhinandan Saikia, Pijush Dutta, Dipankar Ghosh, Govinda Pangging and Goswami Anil K. Biodiversity Significance of North East India for the Study of Natural Resources, Water and Environmental Nexus for Development and Growth in North Eastern India. Background paper no. 13. World Wildlife Fund. New Delhi: 80 pages, 2006.

Das, Manosh. A Khasi pilgrimage to 'heaven's navel on earth (Times of India, Feb 6, 2012): <http://articles.timesofindia.indiatimes.com/2012-02-06/guwahati/31030049 _1_umbilical-cord-earth-huts $>$.

Himmelfarb, David. In the Aftermath of Displacement: A Political Ecology of Dispossession, Transformation, and Conflict on Mt. Elgon, Uganda. University of Georgia, Athens, GA. Dissertation for Ph.D in Anthropology, 2012. 
IWGIA - The Indigenous world (2007) The Horn of Africa and East Africa: < http://www .forestpeoples.org/documents/africa/uganda_iw_2007.pdf >.

International Expert Group Meeting on Indigenous Peoples: Development with Culture and Identity: Articles 3 and 32 of the United Nations Declaration on the Rights of Indigenous Peoples, 12-14 January 2010: <www.un.org/esa/socdev/unpfii/ documents/EGM_DCI_Concept_Paper.doc>.

Mansuri, Ghazala and Vijayendra Rao. Community-Based (and Driven) Development: A Critical Review. Development Research Group, Washington. The World Bank, 2003.

Safitri, Myrna A. and Rafael Edy Bosko Indigenous peoples/ethnic minorities and poverty reduction Indonesia Environment and Social Safeguard Division, Regional and Sustainable Development; Asian Development Bank, Manila, Philippines, 2002.

NF HS-3. International Institute for Population Sciences (IIPS) and Macro International. In National Family Health Survey (NFHS-3), 2005-06: India: Volume I. Mumbai: IIPS, 2007.

Ruby, Jay. "The moral burden of authorship in ethnographic film," Visual Anthropology Review,Volume 11, Number 2, Fall 1995.

Sandell, Richard. Museums, Society, Inequality. Routledge: New York, 2002.

Sandell, Richard. "Social inclusion, the museum and the dynamics of sectoral change." Museum and Society, 2003, 1(1): 45-62.

Sawian, Bijoya. MythsKhasi, Legends \& Folk Tales. New Dehli: Sanbun Publishers, 2010, 35 .

Stephens, Carolyn, Clive Nettleton, John Porter, Ruth Willis and Stephanie Clark. "Indigenous peoples' health-why are they behind everyone, everywhere?" The Lancet, July 2, 2005, Vol. 366, Issue 9479:10-13.

Tauli-Corpuz, Victoria. The Concept of Indigenous Peoples'self-determined development or development with identity and culture: challenges and trajectories. Tebtebba Foundation, CLT/CPD/CPO/2008/IPS/02. UNEsco Publishers, 2008.

Twaalfhoven, Anita. Boekman 82 Community art, Boekman, 2010.

United Nations Development Program, International Policy Centre for Inclusive Growth, Poverty Practice, Bureau for Development Policy, Poverty in Focus: Indigenizing Development, No. 17, May 2009. 